Folia phoniat. 1977;29:I-IV

\title{
Contents, Vol. 29, 1977
}

\section{No. 1}

International Association of Logopedics and Phoniatrics. XVIIth International Congress of Logopedics and Phoniatrics, Copenhagen, August 15-18, 1977

Main Lectures

Ungeheuer, G. und Wegner, D.: Aussersprachliche menschliche Kommunikation ....

Jordal,J.: Treatment of Severe Language Disorders in Children

Eisenson, J.: Language Rehabilitation of Aphasic Adults: Some Observations on the

State of the Art 61

Vallancien, B.; Gaches, L. et Heitz, J.L.: Appreciation des résultats d'une thérapie vocale $\quad 84$

No. 2

Wissen, I. und Biesalski, P.: Das Frostig-Programm in der klinischen Anwendung bei visuellen Wahrnehmungsstörungen sprachgestörter und hörgeschädigter Kinder . 109 Moser,M. und Kittel, G.: Rechnergestützte Tonhöhenbestimmung 119 Ulbrich, H.|' Simon, B.; Wendler, J. und Heinicke, A.-M.: Zur übungstherapeutischen Arbeit an einer phoniatrischen Abteilung 127

Morávek, M.; Bures, P., and Krekule, I.: Temporal Pattern of Vocalized and Silent Segments in Loud Reading 146

Farmer, A.: Stop Cognate Production Patterns in Adult Athetotic Cerebral-Palsied Speakers 154

Stovall, J.V.; Manning, W.H., and Shaw, C.K.: Auditory Assembly Ability of Children with Mild and Severe Misarticulations $\quad 163$

IALPNews 173

Index IV

No. 3

Breuer, H. und Weuffen, M.: Untersuchung zum sprachlichen und verbosensomotorischen Niveau agrammatisch sprechender Vorschulkinder 177

Pedersen, M.F.: Electroglottography Compared with Synchronized Stroboscopy in Normal Persons 191

Hollien, H.; Girard, G.T., and Coleman, R.F.: Vocal Fold Vibratory Patterns of Pulse Register Phonation 200

Baken, R.J. and Isshiki, N.: Arytenoid Displacement by Simulated Intrinsic Muscle Contraction 206

Dordain, M. and Chevrie-Muller, C: Voice and Speech in Wilson's Disease

Müller, G. and Rossiwall, B.: Reading Time and Articulation under Masking Noise and Altered Spatial Conditions in the Oral Cavity 233

Brown, W.S., jr. and Feinstein, S.H.: Speaker Sex Identification Utilizing a Constant Laryngeal Source 240

No. 4 
Kitzing, P.: Methode zur kombinierten photo- und elektroglottographischen Registrierung von Stimmlippenschwingungen

249

Hirose, H.; Sawashima, M.; Ushijima, T., and Kumamoto, Y.: Eunuchoidism: Voice

Pitch Abnormality as an Autonomous Syndrome 261

Kotten, A.: Unterschiede im Beachten örtlicher und zeitlicher Präpositionen bei Aphasikern 270

Darby, J.K. and Hollien, H.: Vocal and Speech Patterns of Depressive Patients

Andrews, G.; Platt, L.J., and Young, M.: Factors Affecting the Intelligibility of

Cerebral Palsied Speech to the Average Listener

292

Pruszewicz, A.; Obrebowski, A., and Zgorzalewicz, B.: Selected Problems in the Hearing, Voice and Speech Disturbances in the Extrapyramidal Form of Cerebral Palsy 302

Keith, R.W.; Murphy, K.P., and Martin, F.: Acoustic Reflex Measurement in Children with Cerebral Palsy 311

Book Review $\square$ Buchbesprechung · Livre nouveau 315

Author Index 316 